\title{
Binding of benzaldehyde by $\beta$-lactoglobulin, by static headspace and high performance liquid chromatography in different physico-chemical conditions
}

\author{
Isabelle Andriot ${ }^{\mathrm{a} *}$, Isabelle Marin ${ }^{\mathrm{b}}$, Gilles Feron ${ }^{\mathrm{a}}$, Perla Relkin ${ }^{\mathrm{b}}$, \\ Élisabeth Guichard ${ }^{\mathrm{a}}$
}

${ }^{a}$ Laboratoire de recherches sur les arômes, Inra, 17, rue Sully, 21034 Dijon cedex, France ${ }^{\mathrm{b}}$ Laboratoire de biophysique des matériaux alimentaires, département science de l'aliment, Ensia, 1, avenue des Olympiades, 91744 Massy cedex, France

(Received 26 January 1999; accepted 1 July 1999)

\begin{abstract}
The study of binding between $\beta$-lactoglobulin and benzaldehyde was realized using two complementary techniques: static headspace and HPLC techniques. Static headspace analysis shows global retention of benzaldehyde whereas HPLC shows the presence of strong interactions. The interactions were studied in different media (water, $\mathrm{NaCl}\left(50 \mathrm{mmol} \cdot \mathrm{L}^{-1}\right), \mathrm{NaCl}\left(50 \mathrm{mmol} \cdot \mathrm{L}^{-1}\right)$ + ethanol $13 \vee \%$ ), with or without heat treatment. (c) Inra/Elsevier, Paris.
\end{abstract}

$\beta$-lactoglobulin / benzaldehyde / interaction / static headspace / HPLC

Résumé - Étude des liaisons entre le benzaldéhyde et la $\beta$-lactoglobuline par headspace statique et chromatographie liquide haute pression dans des conditions physico-chimiques différentes. $L$ 'étude des interactions entre la $\beta$-lactoglobuline et le benzaldéhyde est réalisée à l'aide de deux techniques complémentaires : la technique de headspace statique et la technique de CLHP. La première met en évidence une rétention globale de l'arôme tandis que la seconde montre la présence d'interactions fortes. Les interactions sont étudiées dans des milieux différents (eau, $\mathrm{NaCl}$ $\left(50 \mathrm{mmol} \cdot \mathrm{L}^{-1}\right), \mathrm{NaCl}\left(50 \mathrm{mmol} \cdot \mathrm{L}^{-1}\right)+$ éthanol $\left.13 \mathrm{v} \%\right)$, avec ou sans traitement thermique. (C) Inra/Elsevier, Paris.

$\beta$-lactoglobuline / benzaldéhyde / interaction / headspace statique / CLHP

* Correspondence and reprints. andriot@arome.dijon.inra.fr

These results are part of european COST Action 96 "Interactions of food matrix with small ligands" and of DGAL program "Physico-chemical interactions between proteins and aroma in aqueous or emulsified media" partly financed by the French Ministry of Agriculture and Fisheries. 


\section{INTRODUCTION}

Flavour perception in foods is highly influenced by interactions between flavour compounds with a variety of non-flavour food matrix components. Understanding the process which influences the binding and release behaviours of aroma compounds from the food matrix is of major significance for improving flavour quality. In fact, flavour compounds have an impact at extremely low concentration even though a small degree of interaction of these compounds with ingredients of food matrix can lead to a change in flavour perception by altering the flavour balance. The strength and the nature of these interactions will affect the release of aroma during mastication. Different studies dealt with the binding of flavour compounds with protein. In most cases, the interactions between protein and volatile compounds were found to be hydrophobic [20]. The protein folding should be responsible for hydrophobic interactions between protein and volatile compounds [28]. In general, hydrocarbons [36], ketones [26] and esters [27] were reversibly bound to proteins through hydrophobic interactions and hydrogen binding. For fatty acids, the interactions are electrostatic [32]. The whey protein $\beta$-lactoglobulin is a member of lipocalin family: its structure is similar to retinol-binding protein [11]. These proteins share a common three-dimensional structural pattern: eight-stranded antiparallel $\beta$-sheets flanked on one side by an $\alpha$-helix constituting a hydrophobic pocket [33]. Retinol and retinol derivatives have been shown to interact specifically with $\beta$-lactoglobulin at a 1:1 molar ratio [10]. For retinal, Wang et al. [35] indicated by fluorescence and circular dichroism that a tryptophan is involved in the binding site. Moreover, aldehydes tend to react chemically with protein amino group, resulting in irreversible binding, as Schiff base [7, 14, 15]. In fact, a covalent binding is observed with aldehydes and arginin present in soy and whey proteins [29]. As benzaldehyde is widely used in flavouring, it is important to know whether the interaction is reversible or not, or if both phenomena occur. In a model system, Hansen and Heinis [15] showed that benzaldehyde flavour intensity significantly dropped when whey protein concentration increased. Hansen and Booker [13] showed that the total percentage of benzaldehyde bound at $\mathrm{pH} 6.7$, increased with $\beta$-lactoglobulin concentration and with heat treatment. Overall binding can be measured using headspace analysis [25], equilibrium dialysis [8] or fluorescence spectroscopy [9]. Headspace analysis reveals the overall flavour binding which can be correlated with the odour perception. Irreversible binding could be evaluated by high vacuum transfer [12] or solvent extraction [22]. In this study, two techniques were used to calculate the percentage of benzaldehyde retention with $\beta$-lactoglobulin. Moreover, the effects of $\mathrm{pH}$, different batches of $\beta$-lactoglobulin, different modes of preparation of samples and heat treatment were studied.

\section{EXPERIMENTAL}

\subsection{Materials}

Two batches $(735,775)$ of commercial $\beta$-lactoglobulin (Besnier Bridel Aliments, Chateaulin, France) were used (purity $>90 \%$ ). The analyses of $\beta$-lactoglobulin batches were performed by Besnier Bridel Aliments. All the characterizations are reported in table 1. HPLC analysis was realized in order to verify the purity of batch 735 . The separation was carried out on a column Nucleosil ${ }^{\varpi}$ in reverse phase C18 (porosity $300 \AA$ ) eluted with a gradient constituted of eluent A $(0.1 \%$ trifluoroacetic acid and $99.9 \%$ pure water $)$ and eluent B ( $0.1 \%$ trifluoroacetic acid, $95 \%$ acetonitrile and $4.9 \%$ pure water). UV detection was realized at $214 \mathrm{~nm}$. Twenty $\mu \mathrm{L}$ of protein solution $\left(0.5 \mathrm{mg} \cdot \mathrm{L}^{-1}\right)$ were injected. By comparison of retention times of standard solution ( $\alpha$-lactalbumin, and $\beta$-lactoglobulin), the percentage of $\beta$-lactoglobulin was evaluated at $92 \%$, and the one of $\alpha$-lactalbumin at $5 \%$ [16]. An electrophoresis analysis (SDS-Page) showed that the two batches of protein contained approximately $60 \%$ of protein monomer, $10 \%$ of pro- 
Table I. Characterizations of $\beta$-lactoglobulin determined by Besnier Bridel Aliments.

Tableau I. Caractéristiques de la $\beta$-lactoglobuline fournies par Besnier Bridel Aliments.

\begin{tabular}{lcc}
\hline & Batch 735 & Batch 775 \\
\hline Moisture \% & 5.4 & 4.2 \\
Nitrogenous matters (on dried extract) \% & 94 & 93.5 \\
Mineral matters \% & 0.4 & 0.5 \\
Sodium mg $100 \mathrm{~g}^{-1}$ & 70 & Non-determined \\
Potassium mg $100 \mathrm{~g}^{-1}$ & 50 & Non-determined \\
Calcium mg $100 \mathrm{~g}^{-1}$ & 25 & Non-determined \\
Magnesium mg-100 g-1 & 5 & Non-determined \\
Chloride \% & 0.5 & Non-determined \\
$\beta$-lactoglobulin / Nitrogenous matters \% & $92^{\mathrm{a}}$ & $>95$ \\
$\alpha$-lactalbumin / Nitrogenous matter \% & $5^{\mathrm{a}}$ & $<2$ \\
BSA / Nitrogenous matter \% & Non-determined & $<1$ \\
pH (solution at $10 \%$ ) & 3.4 & 3.7 \\
Free lactose / powder \% & $0.5^{\mathrm{b}}$ & $0.5^{\mathrm{b}}$ \\
\hline
\end{tabular}

a: HPLC analysis [16].

b: HPLC and enzymatic analyses.

tein dimer and a small quantity of $\alpha$-lactalbumin $[16,21]$. The quantification of free lactose in $\beta$-lactoglobulin powder was realized by HPLC analysis (column Aminex HP 87H, refractometric detection) and by enzymatic bioanalysis (kit 176303, Boehringer Mannheim, Meylan, France).

Benzaldehyde was obtained from IFF (Longvic, France). Its purity was evaluated by GC-MS ( $>95 \%)$. An aqueous solution of labelled $\left[\mathrm{U}-{ }^{14} \mathrm{C}\right]$-benzaldehyde $\left(2072 \mathrm{mBq} \cdot \mathrm{mmol}^{-1}\right)$ was supplied by Isotopchim (Ganagobie, France).

Sodium chloride (RP Normapur) and ethanol were purchased from Prolabo (Fontenay-sousBois, France). Sodium hydroxide was a "Baker analysed" reagent from J.T. Baker (Mallinckrodt Baker France, Noisy-le-Sec, France).

\subsection{Preparation of solutions}

The aroma solutions (from $50 \mathrm{ppm}$ to $1000 \mathrm{ppm}$ ) were prepared daily in pure water containing $\mathrm{NaCl}\left(50 \mathrm{mmol} \cdot \mathrm{L}^{-1}\right)$ adjusted at $\mathrm{pH}=3$ with $\mathrm{HCl}(1 \mathrm{~N})$ or at $\mathrm{pH}=6$ with $\mathrm{NaOH}$ $(1 \mathrm{~N})$.

For the preparation of dispersed protein solution, the solutions of $\beta$-lactoglobulin ( $6 \mathrm{w} \%$ ) were prepared in pure water containing $\mathrm{NaCl}$ $\left(50 \mathrm{mmol} \cdot \mathrm{L}^{-1}\right)$ adjusted at $\mathrm{pH}=3$ with $\mathrm{HCl}(1 \mathrm{~N})$ or at $\mathrm{pH}=6$ with $\mathrm{NaOH}(1 \mathrm{~N})$, with addition of sodium azide $(0.02 \mathrm{w} \%)$. The protein solutions were stored for less than $10 \mathrm{~d}$ at $4{ }^{\circ} \mathrm{C}$. The molar ratio between $\beta$-lactoglobulin and benzaldehyde was included between 0.3 and 6 . For the preparation of dialysed protein solution, the $\beta$-lactoglobulin powder was dissolved $(20 \mathrm{w} \%)$ in ultrapure water. The obtained solution was dialysed against ultrapure water at $4{ }^{\circ} \mathrm{C}$ during $24 \mathrm{~h}$. The tube for dialyses was supplied by Spectra/Por (molecular mass cut-off 6-8 $000 \mathrm{~g} \cdot \mathrm{mol}^{-1}$, diameter $32 \mathrm{~mm}$ ). The dialyse membrane was first placed in distilled water for $30 \mathrm{~min}$ to soften it and eliminate glycerol and heavy metals. The dialysate was then centrifuged $15 \mathrm{~min}$ at $15000 \mathrm{~g}$ to eliminate the insoluble particles. The $\mathrm{pH}$ of the centrifuged solution was adjusted to 6 with $\mathrm{NaOH}(1 \mathrm{~N})$. In the case of the study in a $\mathrm{NaCl}$ $50 \mathrm{mmol} \cdot \mathrm{L}^{-1}$ solution, the ionic strength was adjusted with $\mathrm{NaCl}$ to $50 \mathrm{mmol} \cdot \mathrm{L}^{-1}$. The quantitative determination of protein in solution was realized using Biuret's method. A calibration curve at $540 \mathrm{~nm}$ was realized with the bovine serum albumin (purity $>96-99 \%$ ). The molar ratio between $\beta$-lactoglobulin and benzaldehyde was included between 0.1 and 2.7.

To study the effect of ethanol, the protein solution was dialysed against ultrapure water, and the ethanol was added in the dialysed solution. 
Heat treatment was performed in a thermostatic bath at $76{ }^{\circ} \mathrm{C}$ for $10 \mathrm{~min}$, then the flasks were cooled for $30 \mathrm{~min}$ at $4{ }^{\circ} \mathrm{C}$. Before headspace analysis, the flasks were equilibrated for $30 \mathrm{~min}$ at $30^{\circ} \mathrm{C}$.

\subsection{Samples}

Analyses were done in triplicate, in amber flasks $(40 \mathrm{~mL})$ closed with mininert valves (Supelco, France). The analysed solution by headspace and HPLC was constituted by an equal volume of benzaldehyde solution and protein solution. Analysed solutions, with or without protein, were stirred and equilibrated at $30^{\circ} \mathrm{C}$. The vapour phase was analysed by GC, and the liquid phase by HPLC.

\subsection{Static headspace analysis}

Headspace analysis consists of analysing the vapours in the equilibrium above a sample in a confined atmosphere using gas chromatography. Headspace analysis was realized for the samples without protein, and for the sample with protein. In all the cases, the amount of free aroma was determined. The analyses were realized at equilibrium, i.e. when the concentration of benzaldehyde in the gas phase remains constant. Vapour phase samples $(1 \mathrm{~mL})$ were taken with a gas-tight syringe ( $1 \mathrm{~mL}, \mathrm{SGE})$, and injected on a Carlo Erba 8000 gas chromatograph equipped with a DB-Wax column (J \& W Sci., i.d. $0.32 \mathrm{~mm}, 30 \mathrm{~m}$, film thickness $0.5 \mu \mathrm{m}$ ). The $\mathrm{H}_{2}$ carrier gas velocity was $1.9 \mathrm{~mL} \cdot \mathrm{min}^{-1}$. The temperature of the injector and the flame ionization detector (FID) were $250^{\circ} \mathrm{C}$ and $260^{\circ} \mathrm{C}$ respectively. The FID signal was sampled every $50 \mathrm{~ms}$ using a PC-driven four channel plug-in acquisition board developed in the laboratory [2]. After analysis, the data were processed using software developed in the laboratory [1].

\subsection{HPLC analysis}

Eluent (pure water adjusted at $\mathrm{pH} 3$ or $\mathrm{pH}$ 6) was degassed with helium using an Eluent Degas Module (EDM) from Dionex (Sunnyvallee, CA, USA). An advanced gradient pump (Dionex) with a Rheodyne 9126 injector was equipped with a $25 \mu \mathrm{L}$ peek (polyether ether ketone) loop.

A Lichrosorb 100 Diol $(250 \mathrm{~mm} \times$ i.d. $4.6 \mathrm{~mm}, 10 \mu \mathrm{m}$ particles size, Merck) was chosen for the chromatographic separation. Injections of benzaldehyde solution with or without $\beta$-lactoglobulin were performed.

A double detection was made with a UV spectrophotometric detector (SPD 6A, Shimadzu) and a Pulsed Electrochemical Detection (PED, Dionex). The two detectors were set on line. The procedure has been described in detail elsewhere $[18,19]$. A potential sequence was applied to the gold working electrode: from 0 to $500 \mathrm{~ms}$, $\mathrm{E}_{\text {det }}=0.18 \mathrm{~V}$, from $510 \mathrm{~ms}$ to $630 \mathrm{~ms}$, $\mathrm{E}_{\mathrm{ox}}=0.75 \mathrm{~V}$, from $640 \mathrm{~ms}$ to $1 \mathrm{~s}, \mathrm{E}_{\mathrm{red}}=-0.75 \mathrm{~V}$. The oxidation current was integrated from $300 \mathrm{~ms}$ to $500 \mathrm{~ms}$ at the potential of detection $\left(\mathrm{E}_{\mathrm{det}}\right)$. Quantification was realized with a multichannel chromatography work station $[1,2]$.

\subsection{HPLC analysis with labelled compounds}

The apparatus is constituted of a gradient pump (Gilson, model 303) equipped with an automatic injector (Hitachi, model AS 400) and a UV spectrophotometer coupled with a radioactivity detector (Berthold LB 506-C1). The separation was carried out on a Lichrosorb 100 Diol $(250 \mathrm{~mm} \times$ i.d. $4.6 \mathrm{~mm}, 10 \mu \mathrm{m}$ particles size, Merck) with pure water adjusted at $\mathrm{pH} 3$, at a flow rate of $1.2 \mathrm{~mL} \cdot \mathrm{min}^{-1}$. The system was piloted with the Winflow software (Borland, France). Injections $(100 \mu \mathrm{L})$ of solution prepared as follows were realized: $4 \mu \mathrm{L}$ of labelled benzaldehyde solution were added to $2 \mathrm{~mL}$ of $\beta$-lactoglobulin solution $(3 \%)$. Solutions were injected every $30 \mathrm{~min}$ in order to realize a kinetic analysis.

\section{RESULTS AND DISCUSSION}

\subsection{Comparison of percentage of retention of benzaldehyde determined by two methods}

\subsubsection{Headspace analysis}

Headspace analyses were realized at $\mathrm{pH} 3$ and 6 . This study showed that benzaldehyde was significantly bound to $\beta$-lactoglobulin (table I). The percentage of bound benzaldehyde was calculated from the difference between the slopes obtained with and without protein (figure la). It was 

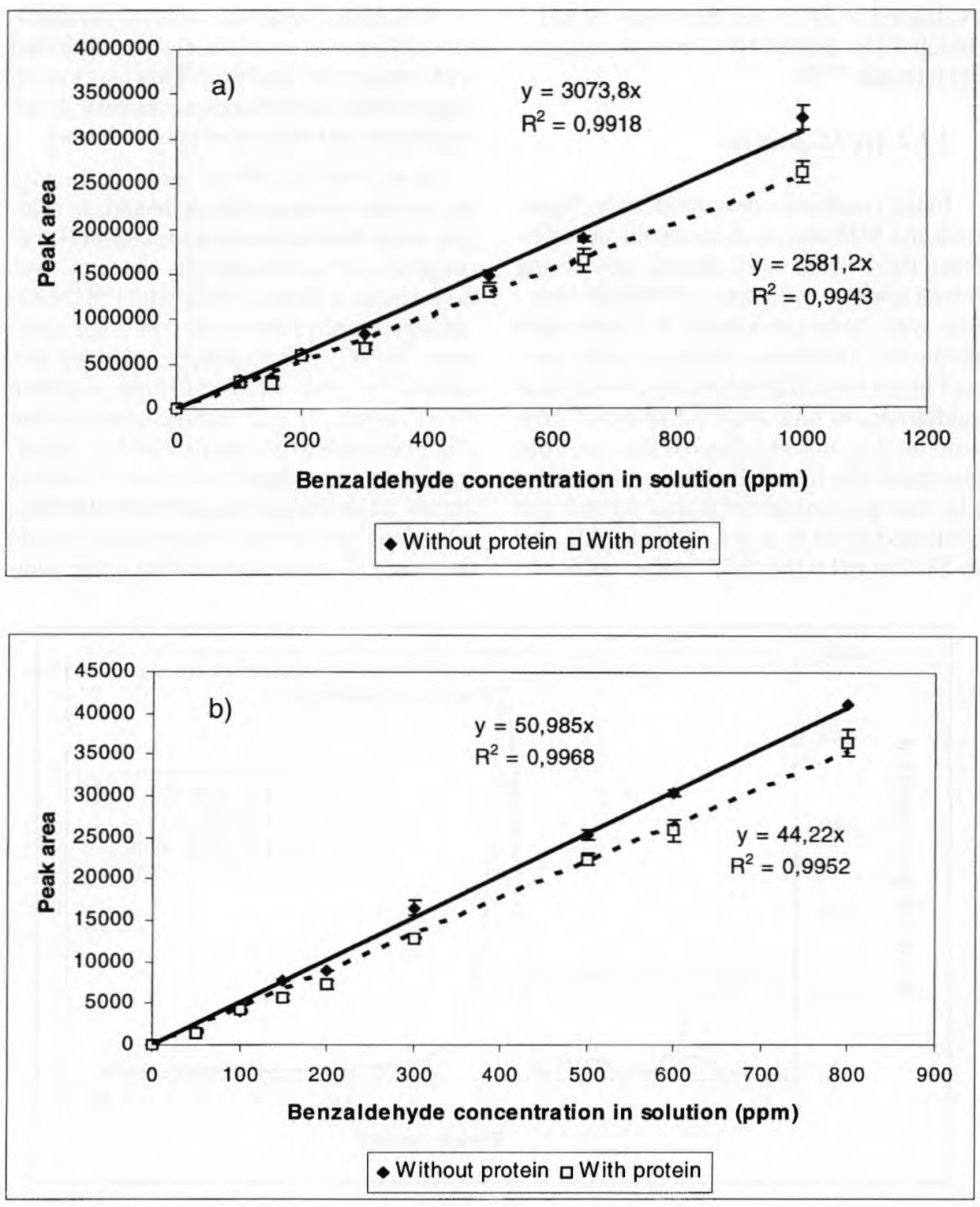

Figure 1. a) Calibration curve of benzaldehyde with and without $\beta$-lactoglobulin at $\mathrm{pH} 6$ by headspace analysis with FID detection. b) Calibration curves of benzaldehyde without and with $\beta$-lactoglobulin at $\mathrm{pH} 6$ by HPLC with PED detection (Lichrosorb $100 \mathrm{Diol}(250 \mathrm{~mm} \times$ i.d. $4.6 \mathrm{~mm}, 10 \mu \mathrm{m}$ particle size, Merck), $\mathrm{V}_{\text {inj }}=25 \mu \mathrm{L}$, room temperature, flow rate $1.2 \mathrm{~mL} \cdot \mathrm{min}^{-1}$, eluent pure water adjusted $\mathrm{pH} 6$ ).

Figure 1. a) Courbes de calibration du benzaldéhyde en présence ou non de $\beta$-lactoglobuline réalisées à $\mathrm{pH} 6$ par analyse headspace avec détection FID. b) Courbes de calibration du benzaldéhyde en présence ou non de $\beta$-lactoglobuline réalisées à $\mathrm{pH} 6$ par CLHP avec détection électrochimique (Lichrosorb $100 \mathrm{Diol}\left(250 \mathrm{~mm} \times\right.$ d.i. $4,6 \mathrm{~mm}$, taille des particules $10 \mu \mathrm{m}$, Merck), $\mathrm{V}_{\mathrm{inj}}=25 \mu \mathrm{L}$, température ambiante, débit $1,2 \mathrm{~mL} \cdot \mathrm{min}^{-1}$, éluant eau pure $\mathrm{pH}$ 6). 
evaluated at $20 \%$ for the assay at $\mathrm{pH} 3$ (batch 735), and at $16 \%$ for the assay at pH 6 (batch 775).

\subsubsection{HPLC analysis}

In the conditions described in the Materials and Methods sections, as the complex is not dissociated in the eluent, only strong interactions were detected. The PED detection was chosen instead of UV detection because of a coelution of benzoic acid (present in the benzaldehyde sample) with benzaldehyde. In fact, the acid group of benzoic acid is not electroreactive on gold electrode due to the alkaline environment [3]. The percentage of bound ligand was evaluated to $20 \%$ at $\mathrm{pH} 3$ (batch 735), and to $13 \%$ at $\mathrm{pH} 6$ (batch775) (figure 1 b).
With HPLC analysis, there is no significant difference with the results obtained with headspace analysis. This leads us to suppose that the interactions between $\beta$-lactoglobulin and benzaldehyde are strong.

As we were not able to measure directly the amount of benzaldehyde bound, an analysis using labelled compounds and an HPLC coupled with a radioactivity detector, was performed. A kinetic study with $\left[{ }^{14} \mathrm{C}\right]$-benzaldehyde and protein was done. The complex $\left[\mathrm{U}-{ }^{14} \mathrm{C}\right]$-benzaldehyde-protein was eluted in the dead volume column $\left(\mathrm{V}=2.8 \mathrm{~mL}, \mathrm{t}_{\mathrm{R}}=2.3 \mathrm{~min}\right)$, whereas free $\left[{ }^{14} \mathrm{C}\right]$-benzaldehyde was detected at $7.6 \mathrm{~mL}$ $\left(\mathrm{t}_{\mathrm{R}}=6.35 \mathrm{~min}\right)$ (figure 2). Figure 2 shows clearly an increase of bound form with time, while the amount of free benzaldehyde decreased. To verify the stability of the com-

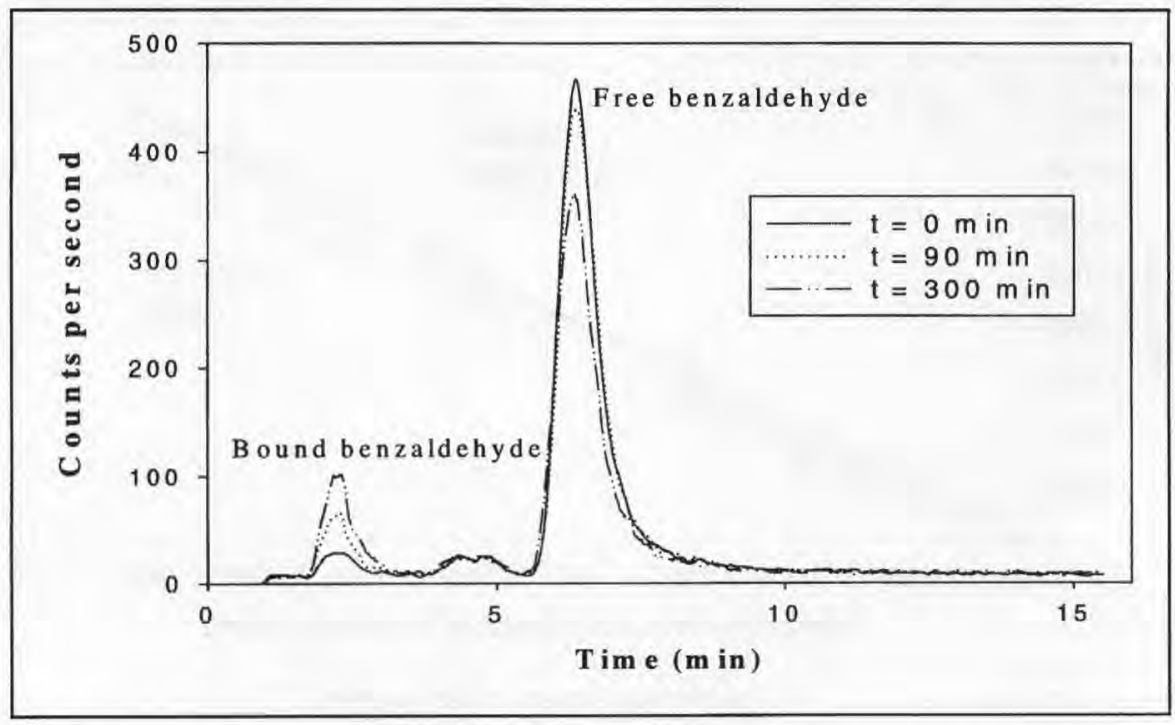

Figure 2. Kinetic effect in binding of radiolabelled benzaldehyde to $\beta$-lactoglobulin: chromatograms with radioactivity detection (Lichrosorb 100 Diol $(250 \mathrm{~mm} \times$ i.d. $4.6 \mathrm{~mm}, 10 \mu \mathrm{m}$ particle size, Merck), $\mathrm{V}_{\text {in }}=25 \mu \mathrm{L}$, room temperature, flow rate $1.2 \mathrm{~mL} \cdot \mathrm{min}^{-1}$, eluent pure water adjusted $\mathrm{pH} 3$ ). Bound $\left[{ }^{14} \mathrm{C}\right]$-benzaldehyde by $\beta$-lactoglobulin at $\mathrm{V}=2.8 \mathrm{~mL}\left(\mathrm{t}_{\mathrm{R}}=2.3 \mathrm{~min}\right)$.

Free $\left[{ }^{14} \mathrm{C}\right]$-benzaldehyde at $7.6 \mathrm{~mL}\left(\mathrm{t}_{\mathrm{R}}=6.35 \mathrm{~min}\right)$.

Figure 2. Cinétique de liaison du benzaldéhyde radioactif à la $\beta$-lactoglobuline : chromatogrammes réalisés avec détection radiométrique (Lichrosorb $100 \mathrm{Diol}(250 \mathrm{~mm} \times$ d.i. $4,6 \mathrm{~mm}$, taille des particules $10 \mu \mathrm{m}$, Merck), $\mathrm{V}_{\mathrm{inj}}=25 \mu \mathrm{L}$, température ambiante, débit $1,2 \mathrm{~mL} \cdot \mathrm{min}^{-1}$, éluant eau pure $\mathrm{pH} 3$ ).

$\left[{ }^{14} \mathrm{C}\right]$-benzaldéhydé lié par la $\beta$-lactoglobuline à $\mathrm{V}=2,8 \mathrm{~mL}\left(\mathrm{t}_{\mathrm{R}}=2,3 \mathrm{~min}\right)$.

$\left[{ }^{14} \mathrm{C}\right]$-benzaldéhyde libre à $7,6 \mathrm{~mL}\left(\mathrm{t}_{\mathrm{R}}=6,35 \mathrm{~min}\right)$. 
plex at equilibrium, non-labelled benzaldehyde was added to the solution, which was stirred for $2 \mathrm{~h}$. The quantity of bound [U${ }^{14} \mathrm{C}$ ]-benzaldehyde was not modified with the addition of non-labelled benzaldehyde. On the other hand, similar experiments, adding [U- $\left.{ }^{14} \mathrm{C}\right]$-benzaldehyde to a solution of $\beta$-lactoglobulin and non-labelled benzaldehyde led to the same results. These data confirmed the strong binding between $\beta$-lactoglobulin and benzaldehyde. However, HPLC experiments did not give information on the nature of the binding. Further experiments are necessary to clarify the covalence of the interactions.

\subsection{Effect of batches}

Two non-dialysed batches of $\beta$-lactoglobulin. ( $3 \%$ ) were used at $\mathrm{pH} 3$. The results of interaction measurements are reported in table II. It was shown that the interactions with batch 735 were stronger than those observed with batch 775 . This could be explained by the different properties between the two batches of $\beta$-lactoglobulin. In fact, Marin [21] has shown that the heat-stability parameters $\left(\mathrm{T}_{\mathrm{p}}, \Delta \mathrm{H}_{\mathrm{app}}\right)$ of batch 775 were higher than those found in the literature. This higher stability could be due to the presence of milk sugars which have been shown to increase the resistance to thermal denaturation of whey proteins [4]. Morgan et al. [23] have shown the Amodari product formation between lactose and $\beta$-lactoglobulin by electrospray ionisation mass spectrometry. The bound lactose stabilized an intermediate state of the denaturation process [5]. On the other hand, the binding of fatty acids to $\beta$-lactoglobulin could be important to stabilize the structure of a protein [30]. At last, batch 735 contains a higher concentration of $\alpha$ lactalbumin ( $5 \%$ instead of less than $2 \%$ ). All these observations could explain the difference observed between the two batches but need to be confirmed by a deeper analysis of the two batches.

\subsection{Effect of $\mathrm{pH}$}

The percentage of retention of benzaldehyde by $\beta$-lactoglobulin was higher at $\mathrm{pH} 6$ (16\%) than at $\mathrm{pH} 3(12 \%)$ (table II). This can be explained by the change of the structure of $\beta$-lactoglobulin, which depends on the $\mathrm{pH}[6,7]$. At $\mathrm{pH} 3$, an equilibrium between monomer and dimer exists whereas at $\mathrm{pH} 6$, the quantity of dimer increases, and the dimeric form is preponderant. Jouenne [17] showed that the retention of three methylketones and three ethyl esters increased when the $\mathrm{pH}$ varied from 2 to 9 . As in our cases, the binding sites seemed to be more accessible at $\mathrm{pH} 6$ than at $\mathrm{pH} 3$.

\subsection{Effect of $\mathrm{NaCl}$}

The interactions measured between benzaldehyde and dialysed $\beta$-lactoglobulin at $\mathrm{pH} 6$ have been shown depending on the nature of the final medium $(25 \%$ in water, $18 \%$ in $\mathrm{NaCl}$ solution). This decrease of retention in the presence of $\mathrm{NaCl}$ could mainly be explained by a salting-out effect [24]. Indeed, without protein, the volatility of benzaldehyde in the presence of $\mathrm{NaCl}$ was higher than in water (slopes respectively equal to 450 and 485 , table $I I$ ). Another explanation could be that the change in the polarity of $\mathrm{H}_{2} \mathrm{O}$ at the protein surface in the presence of salt may influence the retention of benzaldehyde [31].

\subsection{Effect of ethanol}

In the presence of ethanol $(13 \mathrm{v} \%)$ and $\mathrm{NaCl}\left(50 \mathrm{mmol} \cdot \mathrm{L}^{-1}\right)$, the percentage of benzaldehyde retained by the protein was similar to that obtained in the presence of $\mathrm{NaCl}$ only (table II). In these conditions, ethanol did not seem to modify the mechanism of interactions between $\beta$-lactoglobulin and benzaldehyde. However, the headspace technique measured a global effect, and did not distinguish the effect of $\mathrm{NaCl}$ from the effect of ethanol. In fact, ethanol increased the sol- 
Table II. Summary table of results obtained by headspace analysis.

Tableau II. Tableau récapitulatif des résultats obtenus par la technique Headspace.

\begin{tabular}{|c|c|c|c|c|c|c|c|c|c|}
\hline \multirow[b]{3}{*}{ Medium } & \multirow[b]{3}{*}{$\begin{array}{c}\text { Batch } \\
\text { of } \beta \text {-lac }\end{array}$} & \multirow[b]{3}{*}{ Preparation } & \multirow[b]{3}{*}{$\begin{array}{l}\text { Concentration } \\
\text { of protein }(\%)\end{array}$} & \multirow[b]{3}{*}{$\mathrm{pH}$} & \multicolumn{4}{|c|}{ Free Benzaldehyde } & \multirow[b]{3}{*}{$\begin{array}{c}\text { Bound } \\
\text { Benzaldehyde } \\
(\%)\end{array}$} \\
\hline & & & & & \multicolumn{2}{|c|}{ Without protein } & \multicolumn{2}{|c|}{ With protein } & \\
\hline & & & & & $\begin{array}{l}\text { Slope } \\
\text { (a. u.) }\end{array}$ & $\mathrm{R}^{2}$ & $\begin{array}{l}\text { Slope } \\
\text { (a. u.) }\end{array}$ & $\mathrm{R}^{2}$ & \\
\hline \multirow[t]{2}{*}{$\mathrm{NaCl}\left(50 \mathrm{mmol} \cdot \mathrm{L}^{-1}\right)$ Solution } & 735 & Dispersed & 3 & 3 & 3991 & 0.987 & 3197 & 0.9826 & 20 \\
\hline & 775 & Dispersed & 3 & 3 & 4443 & 0.9988 & 3878 & 0.9936 & 12 \\
\hline $\mathrm{NaCl}\left(50 \mathrm{mmol} \cdot \mathrm{L}^{-1}\right)$ Solution & 775 & Dispersed & 3 & 6 & 3074 & 0.9918 & 2581 & 0.9943 & 16 \\
\hline Water & & & & & 450 & 0.9948 & 338 & 0.9963 & 25 \\
\hline $\mathrm{NaCl}\left(50 \mathrm{mmol} \cdot \mathrm{L}^{-1}\right)$ & 775 & Dialysed & 6.9 & 6 & 485 & 0.9843 & 398 & 0.9653 & 18 \\
\hline $\mathrm{NaCl}\left(50 \mathrm{mmol} \cdot \mathrm{L}^{-1}\right)+\mathrm{EtOH} 13 \%$ & & & & & 503 & 0.9894 & 406 & 0.9719 & 20 \\
\hline Water & & Dialysed with & & & 498 & 0.9983 & 367 & 0.9932 & 26 \\
\hline $\mathrm{NaCl}\left(50 \mathrm{mmol} \cdot \mathrm{L}^{-1}\right)$ & 775 & Heat treatment & 6.9 & 6 & 459 & 0.9959 & 410 & 0.9865 & 11 \\
\hline $\mathrm{NaCl}\left(50 \mathrm{mmol} \cdot \mathrm{L}^{-1}\right)+\mathrm{EtOH} 13 \%$ & & $\left(76^{\circ} \mathrm{C}\right.$, or $\left.55^{\circ} \mathrm{C}\right)$ & & & 494 & 0.9986 & 448 & 0.9925 & 10 \\
\hline
\end{tabular}

\section{Water}

$\mathrm{NaCl}\left(50 \mathrm{mmol} \cdot \mathrm{L}^{-1}\right)$

Water

$\mathrm{NaCl}\left(50 \mathrm{mmol} \cdot \mathrm{L}^{-1}\right)+\mathrm{EtOH} 13 \%$
Heat treatment $\left(76^{\circ} \mathrm{C}\right.$, or $\left.55^{\circ} \mathrm{C}\right)$ 
ubility of benzaldehyde in the hydro-alcoholic solution, which decreased the volatility of the aldehyde [34], as opposed to the salting-out effect of $\mathrm{NaCl}$. As shown by fluorescence measurements [21], a $13 \vee \%$ ethanol also had a denaturating effect on $\beta$-lactoglobulin conformation, which could influence the interaction phenomena.

\subsection{Effect of heat treatment}

In the case of water solutions with dialysed $\beta$-lactoglobulin, the heat treatment had no effect on the retention of benzaldehyde. In fact, heat treatment of the $\beta$-lactoglobulin water system caused a denaturation of the protein but was not followed by an aggregation step. However, when the heat treatment of $\beta$-lactoglobulin solution was performed in the presence of $\mathrm{NaCl}$ or ethanol, the interactions were modified: the percentage of retention was divided by two (table II). In these cases, the treatment caused a denaturation of the protein, followed by an aggregation step, which was observed by a change of viscosity and cloudiness of the protein solution. The fact that the $\beta$-lactoglobulin molecules are involved in aggregates of protein can hide the binding sites and decrease their accessibility for the aroma compounds.

\section{CONCLUSION}

The two methods used (headspace and HPLC) gave the same percentage of retention of benzaldehyde by $\beta$-lactoglobulin. Radioactivity measurements confirmed the presence of the complex. Moreover this study showed that the interactions between $\beta$-lactoglobulin and benzaldehyde depended highly on the structure and the environment of the protein:

- The addition of salt decreased the percentage of retention. $\mathrm{In} \mathrm{NaCl}\left(50 \mathrm{mmol} \cdot \mathrm{L}^{-1}\right)$ solution, the percentage of retention of benzaldehyde was shown to be dependent on
$\mathrm{pH}$ but independent of the concentration of protein.

- The addition of ethanol had no effect on the percentage of retention.

- The heat treatment did not modify the behaviour of protein in water solution. On the other hand, in the presence of $\mathrm{NaCl}$ or ethanol, the decrease of retention of benzaldehyde can be explained by an aggregation of $\beta$-lactoglobulin.

\section{ACKNOWLEDGMENTS}

This program was part of a collaborative study between Ensbana (Dijon), Ensia (Massy), Inra (Nantes, Dijon) and GBSA (Montpellier) partly financed by the French Ministry of Agriculture and Fisheries. We thank Besnier Bridel Aliments for providing the protein and IFF for the aroma compound.

\section{REFERENCES}

[1] Almanza R., Couton Y., Mielle P., Nicalordot B., Traitement informatique du signal électrique provenant de calorimètres à flux continu, Cah. Tech. Inra 20 (1989) 49-56.

[2] Almanza R., Mielle P., Deuxième journée de la mesure Inra, Port-Leucate, France, 1990.

[3] Beden B., Cetin 1., Kahyaoglu A., Takky D., Lamy C., Electrocatalytic oxidation of satured oxigenated compounds on gold electrodes, J. Catal. 104 (1987) 37-46.

[4] Bernal V., Jelen P., Thermal stability of whey proteins. A calorimetric study, J. Dairy Sci. 68 (1985) 2847-2852.

[5] Bouhallab S., Morgan F., Henry G., Mollé D., Léonil J., Formation of stable covalent dimer explains the high solubility at $\mathrm{pH} 4.6$ of lactose$\beta$-lactoglobulin conjugates heated near neutral pH, J. Agr. Food Chem. 47 (1999) 1489-1494.

[6] Cayot P., Lorient D., Structures et technofonctions des protéines du lait, Lavoisier Tec \& Doc, Paris, 1998.

[7] Cheftel J.L., Cuq J.L., Lorient D., Les protéines alimentaires - biochimie - propriétés fonctionnelles - valeur nutritive - modifications chimiques, Lavoisier Tec \& Doc, Paris, 1985.

[8] Damodaran S., Kinsella J.E., Flavor protein interactions. Binding of carbonyls to bovine serum albumin: thermodynamic and conformational effects, J. Agr. Food Chem. 28 (1980) 567-571. 
[9] Dufour E., Genot C., Haertlé T., $\beta$-lactoglobulin binding properties during its folding changes studied by fluorescence spectroscopy, Biochim. Biophys. Acta 1205 (1994) 105-112.

[10] Dufour E., Haertlé T., Binding affinities of $\beta$-ionone and related flavor compounds to B-lactoglobulin: effects of chemical modifications, J. Agr. Food Chem. 38 (1990) 1691-1695.

[11] Godovac-Zimmermann J., The structure motif of $\beta$-lactoglobulin and retinol-binding protein: a basic framework for binding and transport of small hydrophobic molecules?, Trends Biochem. Sci. 13 (1988) 64-66.

[12] Gremli H.A., Interaction of flavour compounds with soy protein, J. Am. Oil Chem. Soc. 51 (1974) 95A-97A.

[13] Hansen A.P., Booker D.C., Flavor interaction with casein and whey protein, in: McGorrin R.J., Leland J.V. (Eds), American Chemical Society, Washington, DC, 1994, pp. 75-89.

[14] Hansen A.P., Heinis J.J., Decrease of vanillin flavor perception in the presence of casein and whey proteins, J. Dairy Sci. 74 (1991) 2936-2940.

[15] Hansen A.P., Heinis J.J., Benzaldehyde, citral, and d-limonene flavor perception in the presence of casein and whey proteins, J. Dairy Sci. 75 (1992) 1211-1215.

[16] Jouenne E., Étude des interactions entre la $\beta$-lactoglobuline et les composés d'arôme, thèse, Montpellier-2, 1997.

[17] Jouenne E., Crouzet J., Interaction of aroma compounds between $\beta$-lactoglobulin, in: Taylor A.J., Mottram D.S. (Eds), The Royal Chemical Society of Chemistry, Cambridge, 1996. pp. $425-429$.

[18] Le Fur E., Etievant P.X., Meunier J.M., Comparative investigation of pulsed electrochemical and ultraviolet detections in the determination of flavor-active aldehydes separated by HPLC, J. Agr. Food Chem. 42 (1994) 2760-2765.

[19] Le Fur E., Etievant P.X., Meunier J.M., Interest of pulsed electrochemical detection for the analysis of flavor-active alcohols separated by liquid chromatography, J. Agr. Food Chem. 42 (1994) 320-326.

[20] Le Thanh M., Thibeaudeau P., Thibaut M.A., Voilley A., Interactions between volatile and non-volatile compounds in the presence of water, Food Chem. 43 (1992) 129-135.

[21] Marin L., Contribution à l'étude des interactions entre la $\beta$-lactoglobuline et certains composés d'arôme. Application à la stabilisation des mousses, thèse, université Paris-XI-Paris-Sud, 1998.

[22] Mills O.E., Solms J., Interaction of selected flavour compounds with whey proteins, Lebensm. Wiss. Technol. 17 (1984) 331-335.
[23] Morgan F., Bouhallab S., Mollé D,, Henry G., Maubois J.L., Léonil J., Lactolation of $\beta$-lactoglobulin monitored by electrospray ionisation mass spectrometry, Int. Dairy J. 8 (1998) 95-98.

[24] Nawar W.W., Some considerations in interpretation of direct headspace gas chromatographic analyses of food volatiles, Food Technol. 20 (1966) 115-117.

[25] O'Keefe S., Resurreccion A.P., Wilson L.A., Murphy P.A., Temperature effect on binding of volatile flavor compounds to soy protein in aqueous model systems, J. Food Sci. 56 (1991) 802-806.

[26] O'Neill T.E., Kinsella J.E., Binding of alkanone flavors to $\beta$-lactoglobulin: effects of conformational and chemical modification, J. Agr. Food Chem. 35 (1987) 770-774.

[27] Pelletier E., Sostmann K., Guichard E., Measurement of interactions between $\beta$-lactoglobulin and flavour compounds (esters, acids, pyrazines) by affinity and exclusion chromatography, J. Agr. Food Chem. 46 (1998) 1506-1509.

[28] Plug H., Haring P., The role of ingredientflavour interactions in the development of fatfree foods, Trends Food Sci. Technol. 4 (1993) 150-152.

[29] Plug H., Haring P., The influence of flavouringredient interactions on flavour perception, Food Qual. Preference 5 (1994) 95-102.

[30] Puyol P., Perez M.D., Peiro J.M., Calvo M., Effect of binding of retinol and palmitic acid to bovine $\beta$-lactoglobulin on its resistance to thermal denaturation, J. Dairy Sci. 77 (1994) 1494-1502.

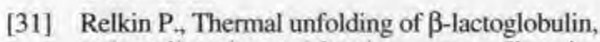
$\alpha$-lactalbumin, and bovine serum albumin. A thermodynamic approach, Crit. Rev. Food Sci. Nutr. 36 (1996) 565-601.

[32] Spector A., Flechter J., Binding of long chain fatty acids to $\beta$-lactoglobulin, Lipids 5 (1970) 403-441.

[33] Uhrinova S., Uhrin D., Denton H., Smith M., Sawyer L., Barlow P.N., Complete assignment of ${ }^{1} \mathrm{H},{ }^{13} \mathrm{C}$ and ${ }^{15} \mathrm{~N}$ chemical shifts for bovine $\beta$-lactoglobulin: Secondary structure and topology of the native state is retained in a partially unfolded form, J. Biomol. NMR 12 (1998) 89-107.

[34] Voilley A., Beghin V., Charpentier C., Peyron D., Interactions between aroma substances and macromolecules in a model wine, Lebensm. Wiss. Technol. 24 (1991) 469-472.

[35] Wang Q., Allen J.C., Swaisgood H.E., Binding of retinoids to $\beta$-lactoglobulin isolated by bioselective adsorption, J. Dairy Sci. 80 (1997) 1047-1053.

[36] Wishnia A., Pinder T. W. J., Hydrophobic interactions in proteins. The alcane binding sites of $\beta$-lactoglobulin A and B, Biochemistry 5 (1966) 1534-1542. 